\title{
Pathomorphology of articular cartilage of the knee and ankle joints in experimental repair of postresection tibial defect using the llizarov method and cement spacer
}

\author{
T.A. Stupina ${ }^{1}$, O.V. Diuriagina ${ }^{1}$, A.A. Emanov ${ }^{1}$, D.S. Mokhovikov ${ }^{1}$, D.Yu. Borzunov ${ }^{2,3}$ \\ ${ }^{1}$ Ilizarov National Medical Research Centre for Traumatology and Orthopedics, Kurgan, Russian Federation \\ ${ }^{2}$ Ural State Medical University, Ekaterinburg, Russian Federation \\ ${ }^{3}$ Central City Clinical Hospital, Ekaterinburg, Russian Federation
}

\begin{abstract}
Objective To explore histomorphological characteristics of articular cartilage of the knee and ankle joints in repair of postresection tibial defects using the Ilizarov method and cement spacer. Material and methods A defect-nonunion was simulated in the proximal tibia of 10 mongrel dogs using the Ilizarov external fixation followed by application of cement spacer to repair a defect-diastasis of at least $15 \%$ of the original bone length. The spacer was removed after 30 days and tibial distraction commenced at a rate of $1 \mathrm{~mm}$ four times at the site of transverse osteotomy in the distal tibia for bone docking. Histomorphological evaluation of articular cartilage of the trochlea of the talus and femoral condyles was produced at 60-day fixation (F60) and 30 days following frame removal (FR30). Results The structure of articular cartilage of the trochlea of the talus was intact at F60 and FR30, and morphometric parameters were comparable with those in controls at the end of experiment. Pannus was detected on the articular surface of the femoral condyles in $60 \%$ of observations, and subchondral bone structure appeared to be impaired with marrow pannus penetrating deep into the cartilage. Intact zonal structure of the cartilage with no pannus, persisted integrity of the basophilic line, thin subchondral bone were observed in $40 \%$ of observations. Compared to controls, greater number of empty lacunes and cartilage thinning were recorded at FR30. Conclusion The Ilizarov external fixation and cement spacer used to repair simulated postresection tibial defect was shown to be a cartilage-sparing procedure for the ankle joint with a higher risk of irreversible destructive changes in articular cartilage of the knee joint.
\end{abstract}

Keywords: tibia defect, Masquelet technique, articular cartilage, histomorphometry

\section{INTRODUCTION}

Large segmental defects of long bones comprise a complex pathology and a difficult challenge for orthopaedic and trauma surgeons $[1,2]$. Reconstructive surgery aims to address bone defects helping to regain skeletal integrity, weight-bearing capacity and function of the limb, improve the cosmetic outcome and regain the ability to work. The clinical outcomes are largely dependent on the operative technique employed [3-5]. Ilizarov techniques of non-free bone graft used to repair bone defects are associated with a long-term fixation period with frame on, multistaged timecosuming treatment and ubiquitous complications [6]. The Masquelet technique of the induced membrane technique is an alternative option for extensive bone defect repair using bone cement as a spacer in the first stage and autologous cancellous bone graft to fill the gap in the second stage [7-9]. In most cases, the rehabilitation period following reconstruction of segmental bone defects is prolonged due to associated anatomical and functional disorders of the limb including joint contractures, limb shortening, scarry soft tissues, impaired regional circulation and infectious complications $[6,10]$ with sporadic cases resulting in total joint replacement [11]. Histological aspects of gradual bone transport affecting the adjacent joints have been underinvestigated [12].

The purpose was to explore histomorphological characteristics of articular cartilage of the knee and ankle joints in repair of postresection tibial defects using the Ilizarov method and cement spacer.

\section{MATERIAL AND METHODS}

Experiments were performed in adult mongrel dogs $(n=10)$ with body weight of $16.8 \pm 0.4 \mathrm{~kg}$ at the age of $3.9 \pm 0.3$ years with tibia length measuring 17 to $20 \mathrm{~cm}$. A nonunion was simulated at the boundary of the tibial upper and middle thirds using the Ilizarov external fixation (patent № 2539627 RF) creating a defect-diastasis of at least $15 \%$ of the original bone length with 60-day fixation with frame on. Fragments' ends were excised to expose the normal bone and a cement spacer was placed into the gap in the second stage. A tight bone-spacer interface using side-toside compression was provided to allow the spacer

Stupina T.A., Diuriagina O.V., Emanov A.A., Mokhovikov D.S., Borzunov D.Yu. Pathomorphology of articular cartilage of the knee and ankle joints in experimental repair of postresection tibial defect using the Ilizarov method and cement spacer. Genij Ortopedii, 2020, vol. 26, no 3, pp. 398-402. DOI 10.18019/1028-4427-2020-26-3-398-402 
adhere strongly to the bone surface after bone cement polimerization. The spacer was removed after 30 days and tibia distraction commenced after a seven day latency period at a rate of $1 \mathrm{~mm}$ four times per day at the site of transverse osteotomy in the distal tibia to achieve for bone docking. Distraction lasted for 25 to 28 days. The frame was removed after 60 -day fixation. Histomorphological evaluation of articular cartilage of the trochlea of the talus and femoral condyles was produced at 60-day fixation $(\mathrm{F} 60, \mathrm{n}=5)$ and 30 days following frame removal (FR30, $n=5)$.

Animal care and all experimental procedures were in accordance with the European Convention for the protection of vertebrate animals used for experimental and other scientific purposes and Directive 2010/63/ EU of the European Parliament and of the Council on the protection of animals used for scientific purposes. The animals were provided humane care and treatment in compliance with SP 2.2.1.3218-14 "Sanitary and epidemiological requirements for the design, equipment and maintenance of experimental biological clinics (vivariums)", GOST 332152014 Guidelines for the maintenance and care of laboratory animals. Rules for equipment of premises and organization of procedures, GOST 33217-2014 Guidelines for the maintenance and care of laboratory animals. Rules for the maintenance and care of laboratory carnivores. The study received a favorable opinion from the relevant research ethics committee (Abstract of minutes № 2 (57) dtd 17.05.18).

Articular cartilage and subchondral bone were excised from the weight-bearing portions of the femoral condyles and the trochlea of the talus with a scalpel for histomorphological evaluation. Several specimen were fixed in neutral buffered formalin, decalcified and embedded in paraffin. Sections were then cut and stained with hematoxylin and eosin and Masson's trichrome. Several semi-thin sections (increased area of up to $8 \mathrm{~mm}^{2}$ ) [13, 14] prepared from aldehyde-fixed and resinembedded tissues were stained with methylene blue and basic fuchsin. The Zeiss Opton (Germany) and AxioScope. A1 (Carl Zeiss MicroImaging GmbH, Germany) microscopes and VideoTest-Master-Morphology software (Russia) were used for light microscopy and for digitizing microscope slides. Measurements were produced to determine cartilage thickness $\left(\mathrm{h}_{\mathrm{ch}}, \mathrm{mcm}\right)$, chondrocyte area $\left(\mathrm{S}_{\mathrm{ch}}, \mathrm{mcm}^{2}\right)$, volumetric $\left(\mathrm{VV}_{\mathrm{ch}}\right)$ and numerical $\left(\mathrm{NA}_{\mathrm{ch}}\right)$ chondrocyte density, a share of chondrocytea in isogenous group $\left(\mathrm{NN}_{\mathrm{is}, \mathrm{r},}\right.$, \%) and a share of empty lacunes $\left(\mathrm{NN}_{\text {em.lac. }}\right.$ \%) in a 200 lacune sample. Articular cartilage of intact animals was a control $(n=5)$. Statistical data analysis was performed using variation and non-parametric tests. Microsoft Office Excel 97 and AtteStat program, version 1.0 were used to complete data analysis reports. Wilcoxon rank-sum tests were conducted for hypothesis testing.

\section{RESULTS}

General condition of animals was satisfactory throughout the experiment. The mean fixation period with frame on was 178 days. Bone resorption at the pin sites of the proximal tibia was noted in all animals during the whole period of observation with a moderate amount of serous exudate from the pin site that resulted in instability of the bone-fixator system and a tendency to antecurvatum and valgus alignment. Wires were reinserted at the second and third surgical phases to prevent bone instability. The dogs developed muscle atrophy and reduced weight-bearing capability

of the operated limb. Macroscopically the animals demonstrated smooth, glazing, bluish white articular surfaces of the trochlea of the talus throughtout the whole period of the experiment. Articular cartilage structure and cytoarchitechtonics over the zones, integrity of the basophilic line appeared to be maintained (Fig. 1, a). Isogenous groups were seen everywhere in cartilage with single empty lacunes noted. Basophilic line and subchondral bone were shown to be sustainable everywhere. The superficial area was not frayed and pannus not detected (Fig. 1, b).
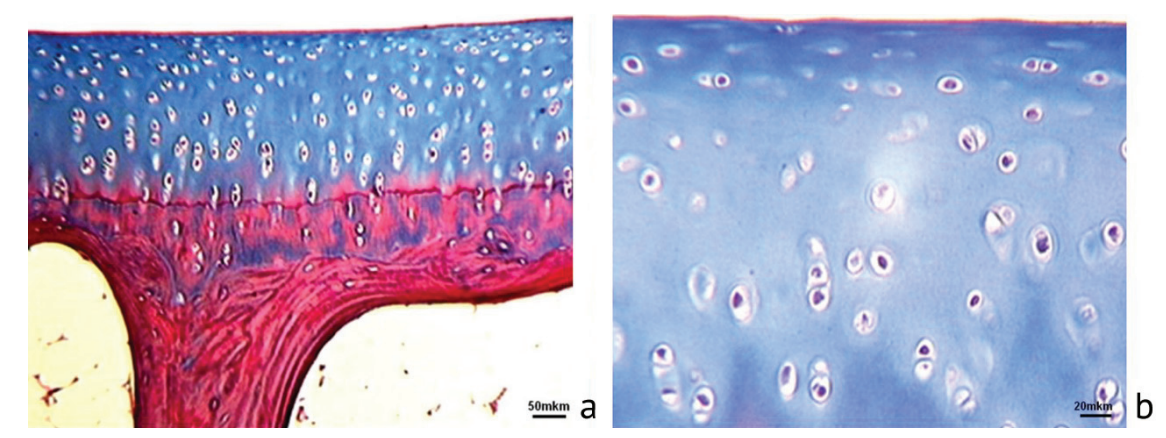

Fig. 1 Paraffin sections of articular cartilage of the trochlea of the talus showing $(a)$ a general view at F60 and superficial and intermediate cartilage zones at FR30 (b). Masson's trichrome staining. 78.75× Magnification $(a), 200 \times$ Magnification $(b)$ 
Histomorphological evaluation showed decrease in morphometric parameters $\mathrm{VV}_{\mathrm{ch}}, \mathrm{NA}_{\mathrm{ch}}, \mathrm{S}_{\mathrm{ch}}, \mathrm{h}_{\mathrm{cr}}$, and a greater amount of empty lacunes and isogenous groups at F60. Chondrocyte area and a share of isogenous groups were superior to those in controls and $\mathrm{NA}_{\mathrm{ch}}, \mathrm{VV}_{\mathrm{ch}}, \mathrm{h}_{\mathrm{cr}}$ were comparable with those in controls (Table 1).

Macroscopic evaluation of articular cartilage of the femoral condyles showed thin, nonglare, purple, irregularly shaped surfaces. Vascular pannus, impaired zonal structure of cartilage and subchondral bone were observed on the articular surface of six dogs out of ten ( $\mathrm{n}=3$ at F60, $\mathrm{n}=3$ at FR30) (Fig. 2, a, b, d).

Articular cartilage appeared to be thin under the pannus with impaired cytoarchitechtonics, columntype cell arrangement being absent in the deep layer; two-, three- and four-membered groups noted with empty lacunes seen everywhere in cartilage. There were areas with absent basophilic partition and calcific cartilage. Integrity of subchondral bone appeared to be impaired with bone marrow pannus and vessels invading deep in cartilage (Fig. 2, a, c). Four dogs $(\mathrm{n}=2$ at $\mathrm{F} 60, \mathrm{n}=2$ at FR30) showed persisted zonal structure of articular cartilage with no pannus detected (Fig. 2, c). Basophilic line appeared to be intact with subchondral bone thinning. Histomorphological evaluation showed increase in numerical density of the cells and decrease in volumetric density due to the less area, and greater dynamics in the parameters was observed at the end of experiment as compared to the previous observation phase. A share of empty lacunes and isogenous groups persisted at FR30 with numeric density of chondrocytes being higher than that in controls. Measurements of cartilage thickness showed less values throught the period of observation as compared to those in controls (Table 2).

Table 1

Histomorphological characteristics of articular cartilage of the trochlea of the talus

\begin{tabular}{|l|c|c|c|c|c|c|}
\hline Parameter & $\mathrm{VV}_{\mathrm{ch}}(\%, \mathrm{M} \pm \mathrm{m})$ & $\mathrm{NA}_{\mathrm{ch}}(\mathrm{M} \pm \mathrm{m})$ & $\mathrm{S}_{\mathrm{ch}}\left(\mathrm{mcm}^{2}, \mathrm{M} \pm \mathrm{m}\right)$ & $\mathrm{NN}_{\mathrm{em} \mathrm{lac}}(\%)$ & $\mathrm{NN}_{\mathrm{is} g \mathrm{r}}(\%)$ & $\mathrm{h}_{\mathrm{cr}}(\mathrm{mcm}, \mathrm{M} \pm \mathrm{m})$ \\
\hline Control & $5.97 \pm 0.36$ & $8.95 \pm 0.51$ & $66.62 \pm 3.95$ & 11.4 & 8.9 & $259.15 \pm 7.81$ \\
\hline F60 & $\mathbf{4 . 2 9} \pm \mathbf{0 . 6 3}$ & $\mathbf{6 . 5 9} \pm \mathbf{0 . 7 7}$ & $\mathbf{5 1 . 7 7} \pm \mathbf{6 . 8 8}$ & 16.92 & 10.85 & $\mathbf{2 0 5 . 8 4} \pm \mathbf{2 . 7 7}$ \\
\hline FR30 & $5.63 \pm 0.64$ & $7.59 \pm 0.71$ & $\mathbf{7 3 . 5 1} \pm \mathbf{5 . 0 7}$ & 12.84 & 16.7 & $248.21 \pm 3.49$ \\
\hline
\end{tabular}

Note: significant differences with controls at $\mathrm{p}<0.05$ typed bold.
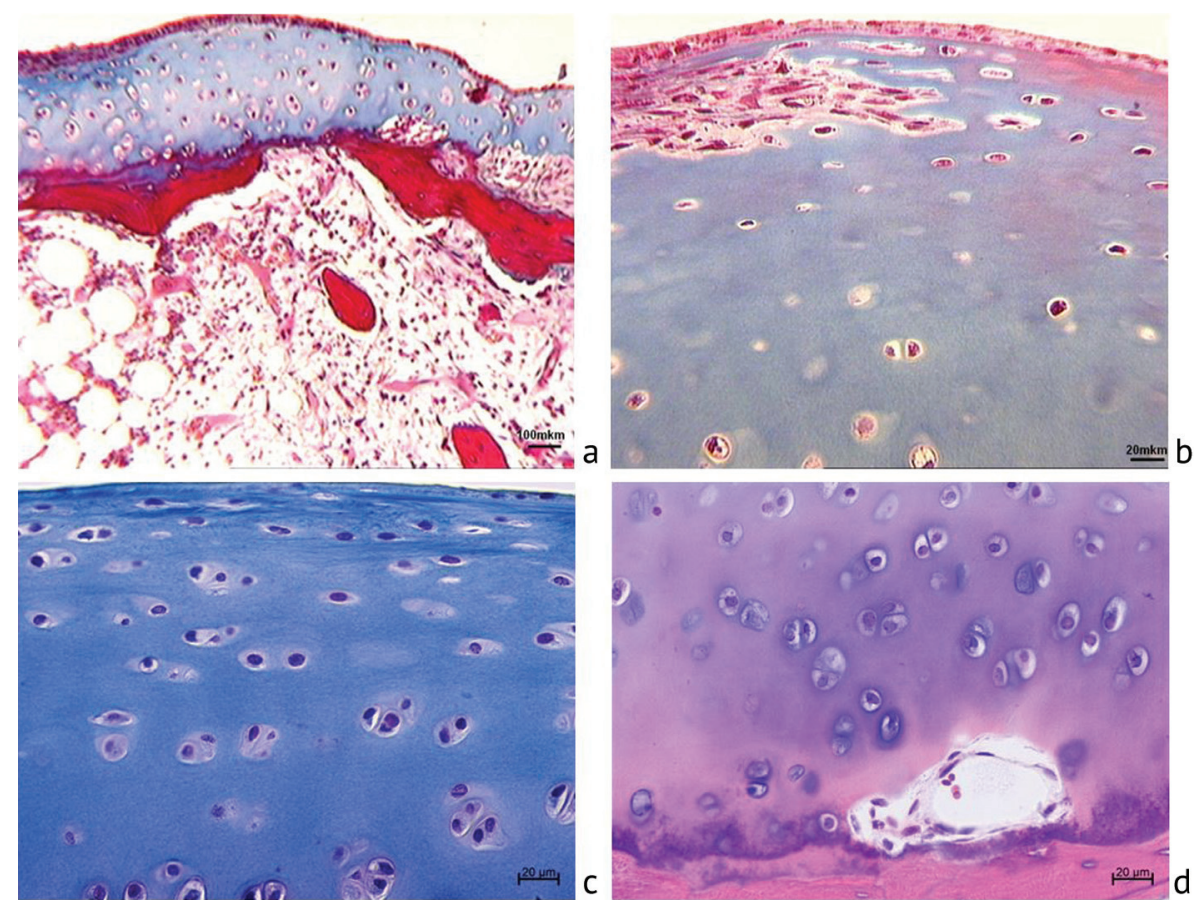

Fig. 2 Paraffin sections of articular cartilage of the femoral condyles showing (a) a general view and $(b)$ the pannus invading the superficial zone at F60; (c) the articular surface without pannus and $(d)$ vessels deep in cartilage at FR30. Masson's trichrome staining $(a, b, c), \mathrm{H} \& \mathrm{E}(\mathrm{d}) .31 .25 \times$ Magnification (a), 500× Magnification $(b, c, d)$

Table 2

Histomorphological characteristics of articular cartilage of the femoral condyles

\begin{tabular}{|c|c|c|c|c|c|c|}
\hline Parameter & $\mathrm{VV}_{c h}(\%, \mathrm{M} \pm \mathrm{m})$ & $\mathrm{NA}_{\mathrm{ch}}(\mathrm{M} \pm \mathrm{m})$ & $S_{c h}\left(\mathrm{mcm}^{2}, M \pm m\right)$ & $\mathrm{NN}_{\mathrm{em} \text { lac }}(\%)$ & $\mathrm{NN}_{\mathrm{isgr}}(\%)$ & $\mathrm{h}_{\mathrm{cr}}(\mathrm{mcm}, \mathrm{M} \pm \mathrm{m})$ \\
\hline Control & $9.03 \pm 1.04$ & $6.1 \pm 0.78$ & $87.5 \pm 3.79$ & 13.61 & 14.5 & $475.5 \pm 1.3$ \\
\hline F60 & $3.87 \pm 0.29$ & $8.85 \pm 0.44$ & $45.72 \pm 3.16$ & 17.5 & 8.96 & $327.07 \pm 4.13$ \\
\hline FR30 & $6.34 \pm 0.51$ & $9.37 \pm 0.58$ & $62.83 \pm 1.52$ & 24.6 & 16.3 & $342.91 \pm 5.13$ \\
\hline
\end{tabular}

Note: significant differences with controls at $\mathrm{p}<0.05$ typed bold. 


\section{DISCUSSION}

The Ilizarov external fixation and cement spacer used to repair simulated postresection tibial defect was shown to be a cartilage-sparing procedure for the ankle joint with intact articular cartilage structure of the trochlea of the talus and morphometric parameters being comparable at the end of experiment. The ankle joint has a very low prevalence of osteoarthritis compared to the knee joint. Specific architechtonics in the superficial zone of articular cartilage can be responsible for the difference in occurrence of osteoarthritis (presence of horizontally oriented isogenous groups of cells) and cartilage regenerative potential $[15,16]$. Condrocyte death is reported to be more severe in articular cartilage of the femoral condyles of intact animals than in articular cartilage of the trochlea of the talus with a greater amount of empty lacunes [17]. The phenomenon was observed in this experiment with increased amount of empty lacunes seen in articular cartilage of the femoral condyles and greater amount of isogenous cell groups in articular cartilage of the trochlea of the talus. Pannus was detected on the articular surface of the femoral condyles in $60 \%$ of observations, and subchondral bone structure appeared to be impaired with marrow pannus penetrating deep in cartilage. Vessels penetrating from the articular surface and subchondral bone into the cartilage were suggestive of impaired chondrohematic barrier, increased oxidative and hydrolytic processes that led to the development of necrotizing calcified cartilage [18].

The appearance of a vascular pannus on the articular surface can result from destructive changes in the periarticular tissues. Impaired structure of the basophilic partition with vessels penetrating deep in articular cartilage can be associated with destruction of underlying subchondral bone, deficient circulation, denervated tibialis anterior muscle, destruction of the peroneal nerve [19] due to unstable fixation, long-term bone fixation with frame on and multistage operative interventions. Correlation between the severity of cartilage destruction, inflammation of the synovium and stability of bone fixation was demonstrated during canine tibial lengthening performed at the metadiaphysis at a rate of $1 \mathrm{~mm}$ four times per day [20]. Destructive and reparative changes in articular cartilage, synovitis and no pannus were reported in the previous experimental series with favorable biomechanical conditions provided with Ilizarov transosseous osteosynthesis for tibial defect repair [12].

Articular cartilage has obvious and fundamental roles in joint function being a unique and multifaceted tissue. Articular cartilage has poor ability to regenerate and cartilage lesions left untreated have limited intrinsic healing capacity for spontaneous repair [21].

Pathological changes in articular cartilage of the femoral condyles appeared to be irreversible in six animals.

\section{CONCLUSION}

The Ilizarov external fixation and cement spacer used to repair simulated postresection tibial defect was shown to be a cartilage-sparing procedure for the ankle joint with a higher risk of irreversible destructive changes in articular cartilage of the knee joint noted in $60 \%$ of the cases.

\section{REFERENCES}

1. Molina C.S., Stinner D.J., Obremskey W.T. Treatment of traumatic segmental long-bone defects: A critical analysis review. JBJS Rev., 2014, vol. 2, no. 4. DOI: 10.2106/JBJS.RVW.M.00062.

2. Giannoudis P.V. Treatment of bone defects: bone transport or the induced membrane technique? Injury, 2016, vol. 47, no. 2, pp. 291292. DOI: $10.1016 /$ j.injury.2016.01.023.

3. Morris R., Hossain M., Evans A., Pallister I. Induced membrane technique for treating tibial defects gives mixed results. Bone Joint J., 2017, vol. 99-B, no. 5, pp. 680-685. DOI: 10.1302/0301-620X.99B5.BJJ-2016-0694.R2.

4. Shevtsov V.I., Borzunov D.Yu. Reabilitatsiia patsientov s defektami i lozhnymi sustavami dlinnykh kostei, sovremennoe sostoianie problemy [Rehabilitation of patients with long bone defects and pseudoarthroses, current state of the problem]. Genij Ortopedii, 2008, no. 4, pp. 48-54. (in Russian)

5. Barabash A.P., Kesov L.A., Barabash Iu.A., Shpiniak S.P. Zameshchenie obshirnykh diafizarnykh defektov dlinnykh kostei konechnostei [Filling extensive shaft defects of limb long bones]. Travmatologiia i Ortopediia Rossii, 2014, no. 2 (72), pp. 93-99. (in Russian)

6. Shastov A.L., Kononovich N.A., Gorbach E.N. Problema zameshcheniia posttravmaticheskikh defektov dlinnykh kostei v otechestvennoi travmatologo-ortopedicheskoi praktike (obzor literatury) [Management of posttraumatic long bone defects in the national orthopedic practice (literature review). Genij Ortopedii, 2018, vol. 24, no. 2, pp. 252-257. (in Russian) DOI: 10.18019/10284427-2018-24-2-252-257.

7. Sivakumar R., Mohideen M.G., Chidambaram M., Vinoth T., Singhi P.K., Somashekar V. Management of Large Bone Defects in Diaphyseal Fractures by Induced Membrane Formation by Masquelet's Technique. J. Orthop. Case Rep., 2016, vol. 6, no. 3, pp. 5962. DOI: $10.13107 /$ jocr.2250-0685.508.

8. Han W., Shen J., Wu H., Yu S., Fu J., Xie Z. Induced membrane technique: Advances in the management of bone defects. Int. J. Surg., 2017, vol. 42, pp. 110-116. DOI: 10.1016/j.ijsu.2017.04.064. 
9. Saxer F., Eckardt H. Rekonstruktion ossärer Defekte mit der Masquelet-Technik [Reconstruction of osseous defects using the Masquelet technique]. Orthopade, 2017, vol. 46, no. 8, pp. 665-672. (in German) DOI: 10.1007/s00132-017-3443-1.

10.Mironov S.P., Kakorina E.P., Andreeva T.M., Ogryzko E.V. Sostoianie travmatologo-ortopedicheskoi pomoshchi naseleniiu rossiiskoi federatsii [Status of traumatologic-and-orthopaedic care to the RF population]. Vestnik Travmatologii $i$ Ortopedii im. N.N. Priorova, 2007, no. 3, pp. 3-10. (in Russian)

11.Giotikas D., Tarazi N., Spalding L., Nabergoj M., Krkovic M. Results of the Induced Membrane Technique in the Management of Traumatic Bone Loss in the Lower Limb: A Cohort Study. J. Orthop. Trauma, 2019, vol. 33, no. 3, pp. 131-136. DOI: 10.1097/ BOT.0000000000001384.

12.Emanov A.A., Stupina T.A., Borzunov D.Y., Shastov A.L. Osobennosti strukturnoi reorganizatsii sustavnogo khriashcha i sinovialnoi obolochki kolennogo sustava pri zameshchenii postrezektsionnogo defekta kostei goleni v usloviiakh chreskostnogo osteosinteza apparatom Ilizarova v eksperimente [Characteristics of structural reorganization of the knee articular cartilage and synovial sheath when filling the post-resection defect of the leg bones under transosseous osteosynthesis using the Ilizarov fixator experimentally]. Mezhdunarodnyi Zhurnal Prikladnykh i Fundamentalnykh Issledovanii, 2015, no. 12-7, pp. 1228-1232. (in Russian)

13.Shchudlo M.M., Varsegova T.N., Stupina T.A., Borisova I.V., Gordichuk S.V., Voinkova L.V., Kobelev A.V. Problema effekta Kholmsa v kolichestvennoi telepatologii (metodicheskie aspekty) [The problem of the Holmes effect in quantitative telepathology (methodological aspects)]. Izvestiia Cheliabinskogo Nauchnogo Tsentra UrO RAN, 2003, no. 1, pp. 120-124. (in Russian)

14.Stupina T.A., Shchudlo M.M. Sposob izgotovleniia preparatov nedekaltsinirovannogo sustavnogo khriashcha s podlezhashchei subkhondralnoi kostiu dlia mnogotselevykh issledovanii [The way of manufacturing the preparations of undecalcified articular cartilage with underlying subchondral bone for multi-purpose studies]. Biulleten Eksperimentalnoi Biologii i Meditsiny, 2014, vol. 157, no. 3, pp. 388-390. (in Russian)

15.Schumacher B.L., Su J.L., Lindley K.M., Kuettner K.E., Cole A.A. Horizontally oriented clusters of multiple chondrons in the superficial zone of ankle, but not knee articular cartilage. Anat. Rec., 2002, vol. 266, no. 4, pp. 241-248. DOI: 10.1002/ar.10063.

16.Rolauffs B., Williams J.M., Grodzinsky A.J., Kuettner K.E., Cole A.A. Distinct horizontal patterns in the spatial organization of superficial zone chondrocytes of human joints. J. Struct. Biol., 2008, vol. 162, no. 2, pp. 335-344. DOI: 10.1016/j.jsb.2008.01.010.

17.Stupina T.A., Stepanov M.A. Otsenka chislennosti khondrotsitov v sustavnom khriashche pri distraktsionnom osteosinteze goleni $\mathrm{v}$ kombinatsii s nakostnoi plastinoi [Estimation of the chondrocyte number in the articular cartilage by combined distraction osteosynthesis of the tibia (Ilizarov apparatus and plating)]. Genij Ortopedii, 2017, vol. 23, no. 4, pp. 467-470. (in Russian)

18.Pavlova V.N., Pavlov G.G., Shostak N.A., Slutskii L.I. Sustav: morfologiia, klinika, diagnostika, lechenie [Joint: morphology, clinical picture, diagnosis, treatment]. M., Meditsinskoe Informatsionnoe Agentstvo, 2011, 552 p. (in Russian)

19.Mokhovikov D.S., Stupina T.A., Varsegova T.N., Diuriagina O.V., Emanov A.A., Borzunov D.Y. Gistomorfometricheskie kharakteristiki perednei bolshebertsovoi myshtsy i malobertsovogo nerva pri eksperimentalnom zameshchenii postrezektsionnogo defekta goleni apparatom Ilizarova v kombinatsii s metodom Masquelet [Histomorphometric characteristics of the anterior tibial muscle and peroneal nerve when experimental filling the leg post-resection defect using the Ilizarov fixator in combination with the Masquelet method]. Genij Ortopedii, 2020, vol. 26, no. 2, pp. 216-221 (in Russian)

20.Stupina T.A., Shchudlo N.A., Petrovskaia N.V.., Stepanov M.A. Gistomorfometricheskii analiz sustavnogo khriashcha i sinovialnoi obolochki kolennogo sustava pri metadiafizarnom udlinenii goleni (eksperimentalno-morfologicheskoe issledovanie) [Histomorphological analysis of the articular cartilage and synovial sheath of the knee in the process of meta-diaphyseal lengthening of the leg]. Travmatologiia i Ortopediia Rossii, 2013, no. 1 (67), pp. 80-86. (in Russian)

21.Makushin V.D., Stupina T.A. K voprosu ob aktivizatsii protsessov, reguliruiushchikh vosstanovlenie struktury sustavnogo khriashcha (obzor literatury i sobstvennye dannye) [To the problem of activating the processes regulating articular cartilage structure recovery (Review of literature and our own data)]. Genij Ortopedii, 2014, no. 1, pp. 82-88. (in Russian)

Received: 31.03.2020

\section{Information about the authors:}

1. Tatyana A. Stupina, Ph.D. of Biological Sciences, Ilizarov National Medical Research Centre for Traumatology and Orthopedics, Kurgan, Russian Federation, Email: StupinaSTA@mail.ru

2. Olga V. Diuriagina, Ph.D. of Veterinary Sciences, Ilizarov National Medical Research Centre for Traumatology and Orthopedics, Kurgan, Russian Federation, Email: diuriagina@mail.ru

3. Andrey A. Emanov, Ph.D. of Veterinary Sciences, Ilizarov National Medical Research Centre for Traumatology and Orthopedics, Kurgan, Russian Federation

4. Denis S. Mokhovikov, M.D., Ph.D.,

Ilizarov National Medical Research Centre for Traumatology and Orthopedics, Kurgan, Russian Federation

5. Dmitry Yu. Borzunov, M.D., Ph.D.,

Ural State Medical University, Ekaterinburg, Russian Federation,

Central City Clinical Hospital, Ekaterinburg, Russian Federation,

Email: borzunov@bk.ru 